\title{
DISTRIBUTION OF BLACK LEAF STREAK DISEASE (Mycosphaerella fijiensis Morelet) IN MATO GROSSO, BRAZIL
}

\author{
DISTRIBUIÇÃO DE SIGATOKA NEGRA (Mycosphaerella fijiensis Morelet) EM \\ MATO GROSSO, BRASIL
}

\section{Omar Roberto da SILVEIRA ${ }^{1}$; Dalci de Jesus BAGOLIN² ${ }^{2}$ Daniel CASSETARI NETO³; Marcia Benedita MARTINS ${ }^{4}$; Reinaldo Moraes da SILVA ${ }^{5}$; Jessica Aparecida Neves de ARAÚJO'}

1. Mestre em Agricultura Tropical, Fiscal Federal Agropecuário, Ministério da Agricultura, Pecuária e Abastecimento, Cuiabá, MT Brasil. omar.silveira@ agricultura.gov.br; 2. Mestre em Defesa Sanitária Vegetal, Fiscal Federal Agropecuário, Ministério da Agricultura, Pecuária e Abastecimento, Cuiabá, MT, Brasil; 3. Professor, Doutor em Fitopatologia, Universidade Federal de Mato Grosso - Campus Cuiabá, MT, Brasil. In memorian; 4. Mestra em Agricultura Tropical, Fiscal Estadual de Defesa Agropecuária e Florestal, Instituto de Defesa Agropecuária do Estado de Mato Grosso, Cuiabá, MT, Brasil; 5. Engenheiro Agrônomo, Fiscal Estadual de Defesa Agropecuária e Florestal, Instituto de Defesa Agropecuária do Estado de Mato Grosso, Confresa, MT; 6. Engenheira Agrônoma, Cuiabá, MT, Brasil.

\begin{abstract}
Banana black leaf streak disease caused by the present quarantine pest $M$. fijiensis occurs in Mato Grosso State since 1999 and requires adoption of sanitation, including detection survey. The aim of this study was to evaluate the distribution of M. fijiensis in Mato Grosso State from 1999 to 2013, as well as how black leaf streak disease periodically was spread in all regions of Mato Grosso State according to the standards of the Ministry of Agriculture, Livestock and Food Supply. Considering the first outbreak year and the previous surveys (Table 1), it can be verified that Mycosphaerella fijiensis Morelet was introduced into Mato Grosso State in accordance with the following periods of times and counties: 2001 to 2003 - Nova Bandeirantes and Paranaíta; 2001 to 2004 - Barra do Bugres and Gaúcha do Norte; 2001 to 2005 - Paranatinga; 2002 to 2004 - Porto Estrela, Santo Afonso, and Tangará da Serra; 2002 to 2005 - Rosário Oeste; 2004 - Acorizal, Guarantã do Norte, and Sinop; 2004 to 2005 - Sapezal; 2005 - Campos de Júlio, Nova Maringá, Poxoréu, and Sorriso; 2005 to 2006 -Marcelândia and Matupá; 2007 - Água Boa, Barra do Garças, Campinápolis, General Carneiro, Novo São Joaquim, and Pedra Preta; 2013 - Canabrava do Norte, Confresa, Porto Alegre do Norte, and São José do Xingu. The dispersal of $M$. fijiensis throughout both time and space showed to be random in Mato Grosso State and its counties, except among some counties adjacent each other, which can be explained by the movement of infected banana seedlings.
\end{abstract}

KEYWORDS: Present quarantine pest. Banana. Dispersal. Mycosphaerella fijiensis.

\section{INTRODUCTION}

Black leaf streak disease is caused by plantpathogenic fungus $M$. fijiensis. It is extremely severe after bunch production because plants do not produce leaves anymore after flowering, which may cause $100 \%$ of yield loss in susceptible cultivars (OROZCO-SANTOS, 1998). M. fijiensis is a regulated pathogen in Brazil as present quarantine pest and requires periodic surveys. This disease is distributed throughout the states of Acre, Amapá, Amazonas, Mato Grosso, Mato Grosso do Sul, Minas Gerais, Pará, Paraná, Rio Grande do Sul, Tocantins, Maranhão, Rio de Janeiro, Rondônia, Roraima, Santa Catarina, and São Paulo (BRASIL, 2013).

Mycosphaerella fijiensis was introduced into Brazil through Amazonas State in 1998 (PEREIRA et al., 2000). In Mato Grosso State since the first detection of black leaf streak in 1999 up to 2004 , the banana cultivated area reduced by $63 \%$ (IBGE, 1999 and 2004). This paper aimed to present the distribution of black leaf streak (M. fijiensis) in Mato Grosso since its first outbreak until 2013.

\section{MATERIAL AND METHODS}

The distribution of this disease was monitored from 1999 to 2013 by the Mato Grosso State Institute of Agricultural and Livestock Defense, know as INDEA/MT. INDEA/MT surveyed black leaf streak according to the Ministry of Agriculture, Livestock, and Food Supply (BRASIL, 2002 and 2005). The surveys sampling and periodicity were the followings: (i) $1 \%$ of rural properties or urban squares at least once each 6 months, in area where the disease has not been detected; (ii) $2 \%$ of rural properties or urban squares at least once each 3 months, in area recognized as M. fijiensis free area by the Ministry of Agriculture, Livestock, and Food Supply; (iii) 5\% of rural properties or urban squares at least once each 2 months, in adjacent area to probable expansion area and to area recognized as $M$. fijiensis free area by 
the Ministry of Agriculture, Livestock, and Food Supply; (iv) 3 adult plants in the pre-flowering stage per hectare at $50 \%$ of existing properties along road considered as risk route for the disease; and (v) 3 adult plants in the pre-flowering stage per hectare, in outbreak delimitation survey according to the following proportions: in 50\% of all properties located at the radius up to $10 \mathrm{~km}$ from the outbreak; in $30 \%$ of all properties located at the radius from 10 to $30 \mathrm{~km}$ measured from the outbreak; and in $10 \%$ of all properties located at the radius from 30 to $70 \mathrm{~km}$ measured from the outbreak. In noncommercial urban and rural areas were inspected at least 3 adult plants in the pre-flowering stage per hectare. In commercial production area were inspected at least 5 adult plants in the preflowering stage per hectare. Plants inspected which were suspected to be infected by this fungus were sampled and analyzed in laboratory accredited by Ministry of Agriculture, Livestock, and Food Supply.

\section{RESULTS AND DISCUSSION}

Black leaf streak was confirmed in 50 counties among 123 counties surveyed, involving all Mato Grosso State regions, through annual surveys which ranged from 1 to 12 in each county (Table 1).

Table 1. Demonstrative of black leaf streak surveys per county with disease occurrence, in Mato Grosso.

\begin{tabular}{|c|c|c|c|c|c|c|c|c|c|c|c|c|c|c|c|}
\hline \multirow[b]{2}{*}{ County } & \multicolumn{15}{|c|}{ Year } \\
\hline & $\vec{b}$ & $\stackrel{\mathbb{8}}{8}$ & $\stackrel{N}{\Theta}$ & 용 & 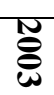 & $\stackrel{\mathbb{8}}{\mathscr{8}}$ & 尽 & ๙ิ & ్ㅗㅇ & $\stackrel{\mathbb{8}}{\mathscr{8}}$ & $\stackrel{\widetilde{8}}{8}$ & $\stackrel{N}{\stackrel{\theta}{\theta}}$ & $\stackrel{N}{\Theta}$ & $\stackrel{N}{\stackrel{N}{\Theta}}$ & $\underset{\omega}{\tilde{\theta}}$ \\
\hline Cuiabá & & & & & & $\mathrm{x}$ & & & & & & & & & \\
\hline Acorizal & & o & & & o & $\mathrm{x}$ & & & & & & & & & \\
\hline Água Boa & o & o & o & & o & o & o & o & $\mathrm{x}$ & & & & & & \\
\hline Apiacás & & & & & $\mathrm{x}$ & $\mathrm{x}$ & & & & & & & & & \\
\hline Aripuanã & & & & & & $\mathrm{x}$ & & & & & & & & & \\
\hline Barra do Bugres & & o & & & & $\mathrm{x}$ & & & & & & & & & \\
\hline Barra do Garças & o & o & & & o & o & o & o & $\mathrm{x}$ & & & & & & \\
\hline Brasnorte & & & & & & $\mathrm{x}$ & & & & & & & & & \\
\hline Cáceres & $\mathrm{x}$ & & o & & & & & & & & & & & & \\
\hline Campinápolis & o & o & o & & & o & o & o & $\mathrm{x}$ & & & & & & \\
\hline Campo Verde & & & & & o & & & & & & & & & & \\
\hline Campos de Júlio & & & & & o & o & $\mathrm{x}$ & & & & & & & & \\
\hline Canabrava do Norte & o & o & o & & & o & & o & o & o & o & o & o & o & $\mathrm{X}$ \\
\hline Castanheira & & & & & & $\mathrm{x}$ & & & & & & & & & \\
\hline Confresa & o & o & o & & & o & & o & o & o & o & o & o & o & $\mathrm{x}$ \\
\hline Cotriguaçu & & & & & & $\mathrm{x}$ & & & & & & & & & \\
\hline Diamantino & & & & & & $\mathrm{x}$ & & & & & & & & & \\
\hline Gaúcha do Norte & o & o & & & & $\mathrm{x}$ & o & & & & & & & & \\
\hline General Carneiro & & & & & o & o & o & o & $\mathrm{x}$ & & & & & & \\
\hline Guarantã do Norte & & o & o & & o & $\mathrm{x}$ & o & $\mathrm{x}$ & $\mathrm{x}$ & & & & & & \\
\hline Itanhangá & & & & & & $\mathrm{x}$ & & & & & & & & & \\
\hline Juara & & & & & & $\mathrm{x}$ & & & & & & & & & \\
\hline Juína & & & & & & $\mathrm{x}$ & & & & & & & & & \\
\hline Juruena & & & & & & $\mathrm{x}$ & & & & & & & & & \\
\hline Marcelândia & & & & & o & o & & $\mathrm{x}$ & o & & & & & & \\
\hline Matupá & & o & & & o & o & & $\mathrm{x}$ & o & & & & & & \\
\hline Nova Bandeirantes & & o & & & $\mathrm{x}$ & $\mathrm{x}$ & & $\mathrm{x}$ & & & & & & & \\
\hline Nova Maringá & & & & & & o & $\mathrm{x}$ & & & & & & & & \\
\hline Nova Monte Verde & & & & & $\mathrm{x}$ & & & & & & & & & & \\
\hline Nova Xavantina & o & o & o & & o & o & o & o & $\mathrm{x}$ & & & & & & \\
\hline Novo Horizonte do Norte & & & & & & $\mathrm{x}$ & & $\mathrm{x}$ & & & & & & & \\
\hline Novo Mundo & & o & o & & o & $\mathrm{x}$ & & & & & & & & & \\
\hline Novo São Joaquim & o & o & o & & o & o & o & o & $\mathrm{X}$ & & & & & & \\
\hline Paranaíta & & o & & & $\mathrm{x}$ & & & & & & & & & & \\
\hline Paranatinga & & o & & & & & $\mathrm{x}$ & & & & & & & & \\
\hline Pedra Preta & & o & & & o & o & o & o & $\mathrm{x}$ & o & $\mathrm{X}$ & o & o & o & \\
\hline
\end{tabular}


Porto Alegre do Norte

Porto dos Gaúchos

Porto Estrela

Poxoréo

Rosário Oeste

Santo Afonso

Santo Antônio do Leverger

São José do Xingu

Sapezal

Sinop

Sorriso

Tabaporã

Tangará da Serra

Tapurah o 0

o $\quad 0$

o

o o

o

o 0

O

$\mathrm{X}$

$\mathrm{X}=$ Survey with outbreak detection $\quad \mathrm{O}=$ Survey without outbreak detection

Considering the first outbreak year and the previous surveys (Table 1), it can be verified that M. fijiensis was introduced into Mato Grosso State according to the following times and counties: 2001 to 2003 - Nova Bandeirantes and Paranaita; 2001 to 2004 - Barra do Bugres and Gaúcha do Norte; 2001 to 2005 - Paranatinga; 2002 to 2004 - Porto Estrela, Santo Afonso, and Tangará da Serra; 2002 to 2005
- Rosário Oeste; 2004 - Acorizal, Guarantã do Norte, and Sinop; 2004 to 2005 - Sapezal; 2005 Campos de Júlio, Nova Maringá, Poxoréu, and Sorriso; 2005 to 2006 - Marcelândia and Matupá; 2007 - Água Boa, Barra do Garças, Campinápolis, General Carneiro, Novo São Joaquim, and Pedra Preta; 2013 - Canabrava do Norte, Confresa, Porto Alegre do Norte, and São José do Xingu (Figure 1).

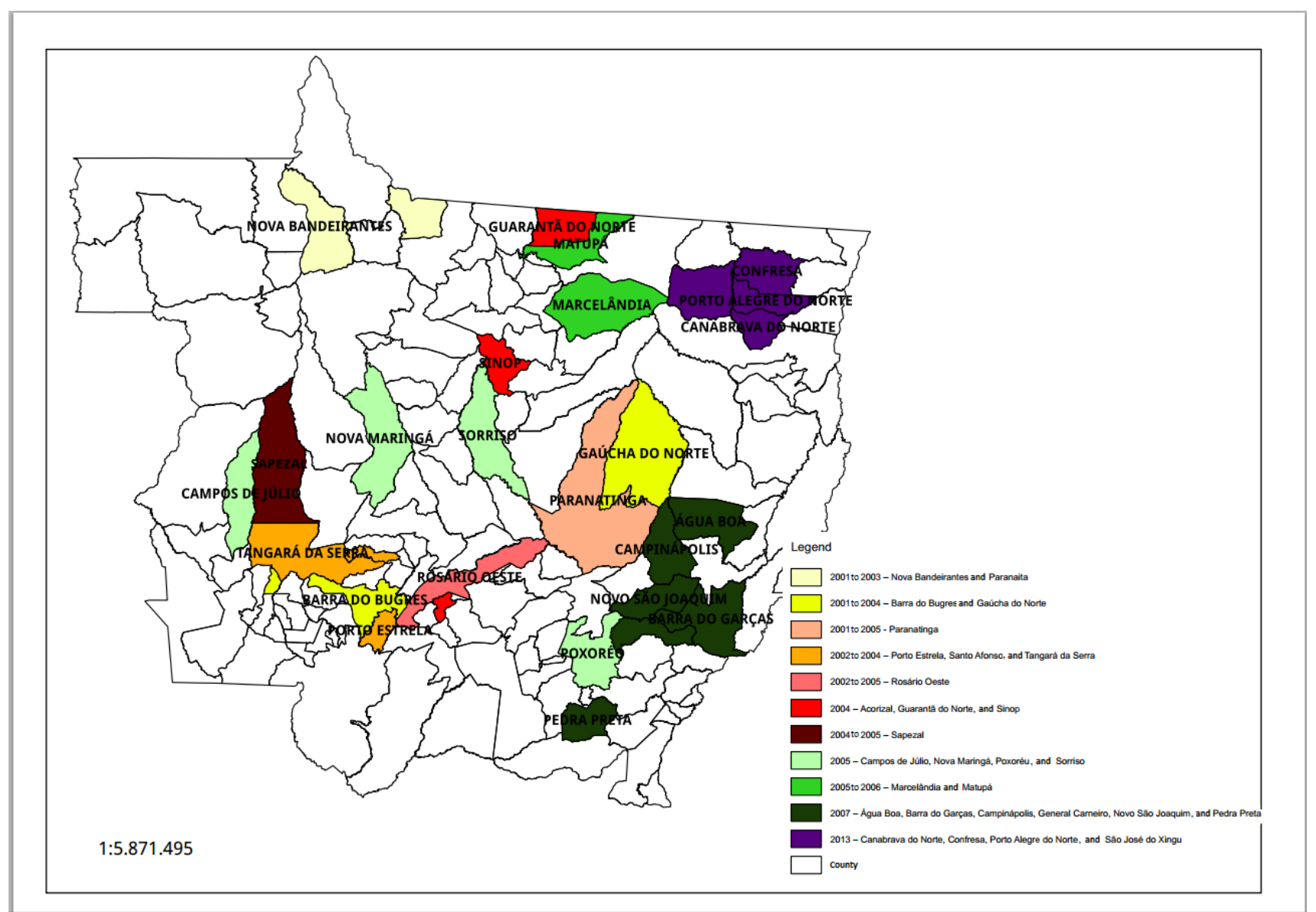

Figure 1. Dispersal of black leaf streak in Mato Grosso State. 
These results showed that black leaf streak did not have homogeneous distribution in Mato Grosso State and not even inside the counties. This fact can be explained by transit of infected seedlings. Silva (2013) confirmed that all properties which received seedlings from Agriculture Secretariat of Confresa County, Mato Grosso State, were contaminated by black leaf streak. That author concluded that probably the disease must have been vehiculated through infected seedlings because the official epidemiological survey showed that all contaminated properties received seedlings both from properties located in Confresa county, Mato Grosso State, and from Mato Grosso State Secretariat of Agriculture. It was possible to conclude that actually infected seedlings distributed in the M. fijiensis free area were responsible for the introduction of this fungus into Canabrava do Norte, Confresa, Porto Alegre do Norte, and São José do Xingu, assuming that: (i) these counties composed a M. fijiensis free area recognized by the Ministry of Agriculture, Livestock, and Food Supply in 2008; (ii) these counties were surveyed each three months, but they became contamined by M. fijiensis in 2013, simultaneously; and (iii) Silva (2013) recorded that in Confresa county black leaf streak dispersal occurred from the outbreak to properties until the radius of $30 \mathrm{~km}$ and the major concentration of dispersal was verified at the radius of $10 \mathrm{~km}$ from the outbreak (Figure 3).

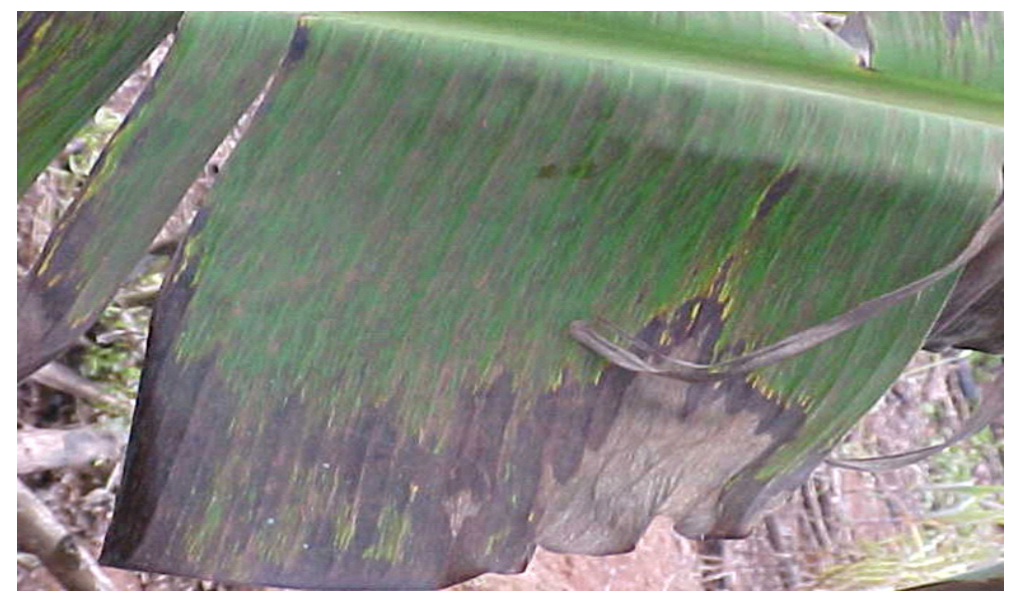

Figure 2. Banana leaf infected by Mycosphaerella fijiensis.

\section{CONCLUSION}

The dispersal of $M$. fijiensis throughout both time and space showed to be random in Mato
Grosso State and its counties, except among some counties adjacent each other, which can be explained by the movement of infected banana seedlings.

RESUMO: O fungo Micosphaerella fijiensis, agente causal da Sigatoka Negra, é uma praga quarentenária presente, que ocorre no estado de Mato Grosso, desde 1999, e exige adoção de medidas fitossanitárias, inclusive levantamentos de detecção. O objetivo deste trabalho foi avaliar a disseminação de M. fijiensis, em Mato Grosso, durante o período de 1999 a 2013, já que a Sigatoka Negra foi levantada em todas as regiões de Mato Grosso, periodicamente, conforme as normas do Ministério da Agricultura, Pecuária e Abastecimento. Determinou-se o ano ou o período em que o fungo M. fijiensis foi introduzido nos municípios, considerando-se o ano de detecção do primeiro foco e o levantamento anterior, resultando na seguinte constatação: (2001 a 2003 - Nova Bandeirantes e Paranaíta); (2001 a 2004 - Barra do Bugres e Gaúcha do Norte); (2001 a 2005 - Paranatinga); (2002 a 2004 - Porto Estrela, Santo Afonso e Tangará da Serra); (2002 a 2005 - Rosário Oeste); (2004 - Acorizal, Guarantã do Norte e Sinop); (2004 a 2005 - Sapezal); (2005 - Campos de Júlio, Nova Maringá, Poxoréu e Sorriso); (2005 a 2006 - Marcelândia e Matupá); (2007 - Água Boa, Barra do Garças, Campinápolis, General Carneiro, Novo São Joaquim e Pedra Preta); (2013 - Canabrava do Norte, Confresa, Porto Alegre do Norte e São José do Xingu). A dispersão desta praga, no tempo e no espaço, mostrou-se aleatória, exceto entre alguns municípios adjacentes entre si, fato que pode ser explicado pelo trânsito de mudas de bananeira contaminadas.

PALAVRAS-CHAVE: Praga quarentenária presente. Banana. Disseminação. Mycosphaerella fijiensis. 


\section{REFERENCES}

BRASIL. Instrução normativa no 41, de 21 de junho de 2002. Brasília: Ministério da Agricultura, Pecuária e Abastecimento. Disponível em: http://sistemasweb.agricultura.gov.br/sislegis. Acesso em: nov. 2015.

BRASIL. Instrução normativa n⿳0 17, de 31 de maio de 2005. Brasília: Ministério da Agricultura, Pecuária e Abastecimento. Disponível em: http://sistemasweb.agricultura.gov.br/sislegis. Acesso em: nov. 2015.

BRASIL. Instrução normativa no 59, de 18 de dezembro de 2013. Brasília: Ministério da Agricultura, Pecuária e Abastecimento. Disponível em: http://sistemasweb.agricultura.gov.br/sislegis . Acesso em: nov. 2015.

IAL - Instituto adolfo lutz. Normas analíticas do instituto adolfo lutz. São Paulo: IAL. v. 1, p. 533, 1985. IBGE - Instituto brasileiro de geografia e estatística. Produção agrícola municipal - culturas temporárias e permanentes. Rio de Janeiro: IBGE. p. 49, 1999. Disponível em:

http://biblioteca.ibge.gov.br/visualizacao/periodicos/66/pam_1999_mt.pdf. Acesso em: nov. 2015.

IBGE - Instituto brasileiro de geografia e estatística. Produção agrícola municipal - culturas temporárias e permanentes. Rio de Janeiro: IBGE. v. 31, p. 19, 2004. Disponível em:

http://biblioteca.ibge.gov.br/visualizacao/periodicos/66/pam_2004_v31_br.pdf. Acesso em: nov. 2015.

OROZCO-SANTOS, M. Manejo integrado de la sigatoka negra del plátano. México: INIFAP (Folheto Técnico, 1), 1998. 95p.

PEREIRA, J. C. R.; GASPAROTTO, L.; COELHO, A. F., VÉRAS, S. M. Doenças da bananeira no estado do Amazonas. Manaus: Embrapa Amazônia Ocidental (Circular Técnica, 7), 2000. 27p.

PEREIRA, J. C. R.; GASPAROTTO, L.; COELHO, A. F.; VÉRAS, S. M. Doenças da bananeira no estado do Amazonas. Manaus: Embrapa Amazônia Ocidental (Circular Técnica, 20), 2003. 15p.

SILVA, R. M. Levantamento de detecção, distribuição espacial e investigação epidemiolóica da sigatoka negra (Mycosfhaerella fijiensis) em área livre no município de Confresa-MT. 2013. 52 p. Monografia (Especialização em Proteção de Plantas), Universidade Federal de Viçosa, 2013. 